\title{
Ukuran Populasi Efektif, Ukuran Populasi Aktual dan Laju Inbreeding Per Generasi Itik Lokal di Kecamatan Tilatang Kamang Kabupaten Agam
}

\section{Effective Population Size, Actual Population Size and Inbreeding Rate of Local Duck at Tilatang Kamang Distric, Agam Regency}

\author{
${ }^{1}$ Rusfidra, ${ }^{2}$ R. Zein dan ${ }^{3}$ A. M. A. Hasibuan \\ ${ }^{1}$ Laboratorium Pemuliaan Ternak, Fakultas Peternakan Univ. Andalas, Padang \\ ${ }^{2}$ Laboratorium Produksi Ternak Ungas, Fakultas Peternakan Univ. Andalas, Padang \\ ${ }^{3}$ Program Studi Produksi Ternak Univ. Andalas, Padang \\ email : rusfidra@gmail.com
}

(Diterima 12 Mei 2012 ; Disetujui 1 Oktober 2012)

\begin{abstract}
This study aims to obtain the effective population size, actual population size and rate of inbreeding of Kamang local duck. In this study used a sample local duck raised from 30 farmers. This research conducted was survey method with purposive random sampling. The variables were calculated in the study, namely the number of adult male ducks (Nm), number of adult female ducks (Nf), number of young male and young female ducks, number of male and female ducklings, actual population size (Na), effective population size (Ne), and the rate of inbreeding per generation $(\Delta F)$. The research was conducted in the District Tilatang Kamang of Agam Regency began on December 23, 2011 until January 25, 2012. The study concluded that the local duck population in the District Tilatang Kamang was 4.131 head. The highest populations were in Nagari Koto Tangah had 1.626 head of ducks. The structure population of the Local duck in the District Tilatang Kamang was an adult male ducks (11.73\%), adult female ducks (24.88\%), young male ducks (12.44\%), young female ducks (13.12\%), drake (13.58\%), and female ducks (13.58\%). Effective population size (Ne) Kamang Local ducks was 1.310 head and the rate of inbreeding per generation is $0.04 \%$.
\end{abstract}

Keywords: effective population size, actual population size, Kamang Local duck, rate of inbreeding.

\section{PENDAHULUAN}

Kegiatan inventarisasi, karakterisasi dan konservasi sumber daya genetik (SDG) perlu dilakukan untuk mengeksplorasi dan mempertahankan plasma nutfah ternak (FAO, 2012; Puslitbang Peternakan, 2011; Rusfidra dan Heryandi, 2010). Evaluasi plasma nutfah bertujuan menjaga kestabilan dan mempertahankan keanekaragaman populasi agar dapat dimanfaatkan semaksimal mungkin untuk kesejahteraan manusia tanpa mengabaikan kaidah-kaidah pelestarian ternak.

Kegiatan eksplorasi sumber daya genetik (SDG) merupakan kegiatan pengumpulan plasma nuftah di dalam maupun di luar habitat. Eksplorasi dilaksanakan untuk mengetahui potensi sumberdaya genetik asli Indo- nesia. Setioko, Sopiyana, dan Sunandar (2005) menyatakan bahwa pada dasarnya kegiatan evaluasi plasma nuftah ternak lokal merupakan kegiatan eksplorasi, identifikasi, evaluasi dan pemanfaatan serta pelestarian ternak lokal yang memiliki potensi genetik asli Indonesia.

Subandriyo (2003) menyatakan bahwa populasi aktual adalah jumlah ternak jantan dan betina dewasa yang digunakan untuk proses perkawinan yang akan menghasilkan bibit. Ukuran populasi efektif (Ne) berkaitan dengan variabilitas genetik yang diperlukan untuk menduga koefisien inbreeding.

Silang dalam (inbreeding) didefenisikan sebagai persilangan antar ternak yang memiliki hubungan kekerabatan lebih dekat dalam populasi tempat individu tersebut berada. Jika kedua tetua berkerabat, anak-anaknya dikata- 
kan inbred. Makin dekat hubungan kekerabatan antara kedua tetuanya maka akan semakin inbred anak-anaknya (Noor, 2008). Perkawinan inbreeding pada ternak sangat besar dampaknya terhadap produktivitas ternak. Tekanan inbreeding pada ternak dapat menyebabkan penurunan performa produksi ternak, meningkatnya mortalitas dan turunnya reproduktivitas (Praharani, Edi dan Budiarsana (2009); (Warwick et al., 1990); Sinar dan Rusfidra, 2007).

Populasi merupakan kumpulan individu suatu spesies yang mempunyai potensi untuk melakukan hubungan secara dinamis antara satu individu atau kumpulan organisme sejenis yang hidup pada daerah tertentu (Warwick et al., 1990). Pengetahuan mengenai ukuran populasi dan laju penurunan populasi suatu rumpun ternak sangat penting untuk mengklasifikasikan status populasi ternak. Salah satu tahap awal dalam program pelestarian plasma nutfah adalah menentukan status populasi ternak. Status populasi dapat ditentukan dengan menghitung jumlah ternak dewasa yang digambarkan dari jumlah betina dewasa dan jumlah populasi efektif (Subandriyo, 2004).

Untuk mengetahui status kerentanan populasi itik Lokal di Kecamatan Tilatang Kamang maka perlu diketahui data struktur populasi itik lokal yang dapat digunakan dalam mendisain program pemuliaan dan konservasi plasma nutfah itik Lokal di Kecamatan Tilatang Kamang.

Penelitian ini bertujuan untuk menghitung struktur populasi, menghitung ukuran populasi efektif (Ne), ukuran populasi aktual $(\mathrm{Na})$ dan laju inbreeding per generasi $(\Delta \mathrm{F})$ itik lokal di Kecamatan Tilatang Kamang Kabupaten Agam.

\section{METODE}

Pada penelitian ini digunakan itik lokal yang dipelihara oleh 30 peternak itik di Tiga Nagari di Kecamatan Tilatang Kamang Kabupaten Agam. Peternak yang dijadikan responden memiliki pengalaman beternak $>3$ tahun dan mempunyai ternak itik >30 ekor. Pengambilan sampel dilakukan dengan cara purposive random sampling. Peubah yang dihitung adalah jumlah itik jantan dewasa (ekor), jumlah itik betina dewasa (ekor), jumlah itik jantan muda (ekor), jumlah itik betina muda (ekor), jumlah anak itik jantan dan anak itik betina (ekor), jumlah populasi aktual (Na), jumlah populasi efektif (Ne) dan laju inbreeding per generasi $(\Delta \mathrm{F})$.

Jumlah populasi aktual dihitung dengan menjumlahkan itik jantan dewasa dengan itik betina dewasa.

$$
\mathrm{Na}=\mathrm{Nm}+\mathrm{Nf}
$$

Jumlah populasi efektif dihitung menurut Hamilton (2009), yaitu:

$\mathrm{Ne}=\frac{(4 \mathrm{Nm} N \mathrm{Nf})}{\mathrm{Nm}+\mathrm{Nf}}$

Laju inbreeding per generasi dihitung menurut Hamilton (2009):

$\Delta \mathrm{F}=\frac{1}{2 \mathrm{Ne}}$

Dimana :

$\mathrm{Nm}=$ Jumlah jantan dewasa (number of breed male).

$\mathrm{Nf}=$ Jumlah betina dewasa (number of breed female).

$\mathrm{Na}=$ Jumlah populasi aktual.

$\mathrm{Ne}=$ Jumlah populasi efektif.

$\Delta \mathrm{F}=$ Laju inbreeding pergenerasi.

Penelitian ini dilakukan dengan metode survey. Penelitian dilaksanakan di Nagari Kapau, Nagari Gadut dan Nagari Koto Tangah Kecamatan Tilatang Kamang Kabupaten Agam dari tanggal 23 Desember 2011 sampai 25 Januari 2012.

Tabel 1. Nagari, Jumlah Peternak dan Jumlah Ternak dari Sampel Itik Lokal di Tilatang Kamang.

\begin{tabular}{clcc}
\hline No & Nagari & $\begin{array}{c}\text { Jumlah } \\
\text { Peternak } \\
\text { (Orang) }\end{array}$ & $\begin{array}{c}\text { Jumlah } \\
\text { Ternak } \\
\text { (Ekor) }\end{array}$ \\
\hline 1. & Kapau & 10 & 1.436 \\
2. & Gadut & 10 & 1.069 \\
3. & Koto Tangah & 10 & 1.626 \\
\hline & Jumlah & 30 & 4.131 \\
\hline
\end{tabular}




\section{HASIL DAN PEMBAHASAN}

\section{Struktur Populasi Itik Lokal di Kecamatan Tilatang Kamang.}

Jumlah populasi dan persentase itik lokal di Kecamatan Tilatang Kamang Kabupaten Agam dapat dilihat pada Tabel 2. Dari keseluruhan sampel itik lokal di tiga Nagari diketahui bahwa populasi ternak itik terbanyak terdapat di Nagari Koto Tangah berjumlah 1.626 ekor itik (39,36\%), diikuti Nagari Kapau berjumlah 1.436 ekor itik $(34,76 \%)$, dan Nagari Gadut berjumlah 1.069 ekor itik $(25,88 \%)$. Jumlah itik jantan dari semua kategori umur di tiga Nagari berjumlah 1.540 ekor itik atau sekitar 37,28\% dari jumlah itik, sedangkan jumlah itik betina dari semua kategori umur di tiga Nagari berjumlah 2.591 ekor atau sekitar $62,72 \%$.

Dari keseluruhan sampel itik lokal di tiga Nagari diketahui bahwa populasi ternak itik terbanyak terdapat di Nagari Koto Tangah berjumlah 1.626 ekor itik $(39,36 \%)$, diikuti Nagari Kapau berjumlah 1.436 ekor itik $(34,76 \%)$, dan Nagari Gadut berjumlah 1.069 ekor itik $(25,88 \%)$. Jumlah itik jantan dari se- mua kategori umur di tiga Nagari berjumlah 1.540 ekor itik atau sekitar $37,28 \%$ dari jumlah itik, sedangkan jumlah itik betina dari semua kategori umur di tiga Nagari berjumlah 2.591 ekor atau sekitar $62,72 \%$.

\section{Populasi Aktual (Na) Itik Lokal di Kecamatan Tilatang Kamang.}

Pada Tabel 3 dapat dilihat bahwa jumlah populasi aktual (Na) itik Lokal di Kecamatan Tilatang Kamang adalah 1.510 ekor. Populasi terbesar berada di Nagari Koto Tangah (597 ekor), diikuti Nagari Kapau (493 ekor) dan Nagari Gadut (420 ekor). Subandriyo (2003) menjelaskan bahwa populasi aktual adalah jumlah ternak jantan dan betina dewasa yang digunakan untuk proses perkawinan yang akan menghasilkan bibit.

\section{Ukuran Populasi Efektif (Ne) dan Laju Inbreeding per Generasi $(\Delta \mathbf{F})$}

Ukuran populasi efektif (Ne) itik Lokal di Kecamatan Tilatang Kamang adalah 1.315 ekor (Tabel 4). Laju inbreeding per generasi itik Lokal di Kecamatan Tilatang Kamang adalah sebesar $0,04 \%$.

Tabel 2. Populasi dan Persentase Itik Lokal di Kecamatan Tilatang Kamang Kabupaten Agam.

\begin{tabular}{llccccccc}
\hline \multirow{2}{*}{ No. Nagari } & \multicolumn{2}{c}{$\begin{array}{c}\text { Itik Dewasa } \\
\text { (ekor) }\end{array}$} & \multicolumn{2}{c}{ Itik Dara (ekor) } & \multicolumn{2}{c}{ Anak itik (ekor) } & \multirow{2}{*}{$\begin{array}{c}\text { Total } \\
\text { (ekor) }\end{array}$} \\
\cline { 3 - 7 } & & Jantan & Betina & Jantan & Betina & Jantan & Betina & \\
\hline 1. & Kapau & 152 & 341 & 219 & 417 & 160 & 147 & 1.436 \\
2. & Gadut & 155 & 265 & 169 & 278 & 101 & 101 & 1.069 \\
3. & Koto Tangah & 177 & 420 & 126 & 310 & 281 & 312 & 1.626 \\
\hline & Total & 484 & 1.026 & 514 & 1.005 & 542 & 560 & 4.131 \\
& $(\%)$ & $(11,72 \%)$ & $(24,84 \%)$ & $(12,44 \%)$ & $(24,33 \%)$ & $(13,12 \%)$ & $(13,56 \%)$ & $(100 \%)$ \\
\hline
\end{tabular}

Tabel 3. Ukuran Populasi Aktual (Na) Itik Lokal di Kecamatan Tilatang Kamang

\begin{tabular}{|c|c|c|c|c|c|}
\hline \multirow[b]{2}{*}{ No. } & \multirow[b]{2}{*}{ Peubah } & \multicolumn{3}{|c|}{ Nagari } & \multirow[b]{2}{*}{$\begin{array}{l}\text { Jumlah } \\
\text { (ekor) }\end{array}$} \\
\hline & & Kapau & Gadut & $\begin{array}{l}\text { Koto } \\
\text { Tangah }\end{array}$ & \\
\hline 1. & $\begin{array}{l}\text { Jumlah itik jantan dewasa (Number of breed } \\
\text { male, Nm). (ekor). }\end{array}$ & 152 & 155 & 177 & 484 \\
\hline 2. & $\begin{array}{l}\text { Jumlah itik betina dewasa (Number of breed } \\
\text { female, Nf). (ekor). }\end{array}$ & 341 & 265 & 420 & 1.026 \\
\hline 3. & Populasi Aktual (Na) (ekor). & 493 & 420 & 597 & 1.510 \\
\hline
\end{tabular}


Tabel 4. Ukuran Populasi Efektif (Ne) dan Laju Inbreeding per Generasi dari Itik Lokal di Kecamatan Tilatang Kamang Kabupaten Agam.

\begin{tabular}{llccccc}
\hline \multirow{2}{*}{ No } & \multicolumn{1}{c}{ Peubah } & \multicolumn{3}{c}{ Nagari } & \multirow{2}{*}{ Total } \\
\cline { 3 - 5 } & \multicolumn{1}{c}{ Kapau } & Gadut & Koto Tangah & \\
\hline 1 & $\begin{array}{l}\text { Jumlah itik jantan dewasa (Number of } \\
\text { breed male, Nm). (ekor). }\end{array}$ & 152 & 155 & 177 & 484 \\
2 & $\begin{array}{l}\text { Jumlah itik betina dewasa (Number of } \\
\text { breed female, Nf). (ekor). }\end{array}$ & 341 & 265 & 420 & 1.026 \\
3 & Jumlah populasi efektif (Ne). (ekor). & 421 & 391 & 498 & 1.315 \\
4 & Laju inbreeding $(\Delta \mathrm{F})(\%)$ & 0,11 & 0,13 & 0,1 & 0,04 \\
\hline
\end{tabular}

Hasil penelitian ini menunjukkan bahwa tekanan silang dalam (inbreeding) dari populasi ternak itik di Kecamatan Tilatang Kamang belum terjadi. Salamena $d k k$. (2007) menyatakan bahwa suatu populasi dapat bertahan apabila laju silang dalam per generasi lebih kecil atau sama dengan $1 \%$. Sementara itu, Praharani dkk. (2009) menyatakan bahwa kenaikan $1 \%$ dari tingkat inbreeding per generasi akan menurunkan produksi dan menyebabkan penurunan sifat performa pada ternak.

\section{KESIMPULAN}

Kesimpulan penelitian ini adalah:

1. Populasi itik Lokal di Kecamatan Tilatang Kamang Kabupaten Agam adalah 4.131 ekor itik yang terdiri atas itik jantan dewasa sebanyak 484 ekor $(11,72 \%)$, itik betina dewasa sebanyak 1.026 ekor $(24,84 \%)$, itik jantan muda sebanyak 514 ekor $(12,44 \%)$, itik betina muda sebanyak $1.005(24,33 \%)$, anak itik jantan sebanyak 542 ekor $(13,12 \%)$, dan anak itik betina sebanyak 560 ekor $(13,56 \%)$.

2. Ukuran populasi aktual (Na) itik Lokal di Kecamatan Tilatang Kamang adalah 1.510 ekor.

3. Ukuran populasi efektif (Ne) itik lokal di Kecamatan Tilatang Kamang adalah 1.315 ekor.

4. Laju silang dalam per generasi pada itik lokal di Kecamatan Tilatang Kamang adalah sebesar $0,04 \%$
Berdasarkan hasil penelitian disarankan kepada peternak untuk meningkatkan jumlah populasi itik Lokal di Kecamatan Tilatang Kamang dalam rangka mempertahankan keberadaan itik Lokal Kamang. Konservasi itik lokal dapat dilakukan oleh peternak itik (on-farm conservation).

\section{DAFTAR PUSTAKA}

FAO.2012. Phenotypic characterization of animal genetic resources.FAO Animal Production and Health Guidelines No. 11. Rome.

Hamilton, M. B. 2009. Population Genetics. Blackwell Publishing, John Wiley \& Sons Ltd, The Atrium, Southern Gate, Chichester, West Sussex,PO19 8SQ, UK.

Noor, R, R. 2008. Genetika Ternak. Cetakan Keempat. Penebar Swadaya. Jakarta.

Notter, D. R., A.S. Mariante dan Z. Sheng. 1994. Modern approaches to active conservation of domestic animal diversity. University of Guelph. Ontario, Canada. Vol. : 509-516.

Praharani, L. E. Juarni dan L. G. M. Budiarsana. 2009. Parameter indikator inbreeding rate pada populasi ternak kerbau di Kabupaten Lebak Provinsi Banten. Makalah pada Seminar dan Lokakarya Nasional Kerbau. Bogor

Pusat Penelitian dan Pengembangan Peternakan. 2011. Rencana Aksi Global Sumber Daya Genetik Ternak Dan Deklarasi Interlaken. Bogor: Pusat 
Penelitian dan Pengembangan Peternakan.

Rusfidra dan Y. Heryandi. 2010. Inventarisasi, karakterisasi dan konservasi sumber daya genetik itik Lokal Sumatera Barat. Laporan Penelitian Strategis Nasional Tahun 2010.

Salamena, J.F., R.R. Noor, C. Sumantri, dan I. Inounu. 2007. Hubungan genetik ukuran populasi efektif dan laju silang dalam per generasi populasi domba di Pulau Kisar. Artikel pada situs http://www.j.indon. trop.anim.agric.com. Diakses 25 Oktober 2011.

Setioko, A.R., S. Sopiyana dan T. Sunandar.
2005. Identifikasi sifat-sifat kualitatif dan ukuran tubuh pada ternak itik Tegal, itik Cirebon dan itik Turi. Makalah pada Seminar Nasional Teknologi Peternakan dan Veteriner.

Sinar, T. E. dan Rusfidra. 2007. Pemuliaan Ternak. Jakarta: Penerbit Universitas Terbuka.

Subandriyo, 2004. Pengelolaan Data Plasma Nutfah Ternak. Buletin Plasma Nutfah 10 (2): 90-100.

Subandriyo. 2003. Konservasi sumberdaya genetik ternak, pertimbangan, kriteria, metoda dan strategi. Artikel pada situs http://www.j.konsv.com. Diakses 15 Juli 2012 